\title{
DAMAGE CAUSED BY THE SNAIL, MARISA CORNUARIETIS, TO YOUNG RICE SEEDLINGS IN PUERTO RICO
}

The fresh-water snail (Marisa cornuarietis) has been found to effectively reduce populations of another snail (Australorbis glabratus Say) in Puerto Rico.' The latter is the alternate host of the human blood fluke (Schistosoma mansoni Sambon), the cause of the debilitating tropical disease "Bilharzia". ${ }^{2}$ A large population of Australorbis began to disappear soon after Marisa was introduced into the pools and streams on the grounds of this Station. Marisa also fed on waterlilies (Nymphae sp.) and other vegetation growing in the ponds. As a result, the question was asked, aside from controlling the intermediate host for the "Bilharzia" organism, could the snail also be used to eliminate undesirable water plants? On the other hand, this snail might prove harmful to water-grown crop plants. Rice is one of these plants, passing a large part of its life cycle submerged in fresh water, and is an extremely important crop in most tropical areas of the world. The purpose of the present work was to determine the effect of Marisa on rice plants at different growing stages.

The test was carried out in one of the small ponds on the grounds of the Federal Experiment Station at Mayagüez. Half of the area was planted with 4-week-old rice plants which were about 8 inches tall. Dry rice seeds were broadcast over the other half of the plot. One week later rice seed, presoaked for 24 hours and with radicules and plumules beginning to emerge, were broadcast over the same area. At the end of the second and third weeks, respectively, soaked seed (48 and 72 hours of presoaking) were broadcast again in the same area. The area was heavily populated with the Marisa snail at time of rice planting. Twenty-five young water-hyacinth (Echhornia crassipes) plants, known to be moderately damaged by this snail, were interplanted among the rice plants to serve as a measure of the snail activity.

The 4-week-old rice plants grew well and apparently suffered no damage from the snail. Ilowever, the young rice seedlings -0 to 72 hours presoaked -and the young water-hyacinth plants were completely destroyed by the snail (fig. 1). After 4 weeks, not a single rice plant resulting from direct seeding remained in the plot.

${ }^{1}$ Chemin, Eli, Michelson, Edward H., and Augustine, Donald L., Studies on the biological control of Schistosome-bearing snails; the control of Australorbis glabratus population by the snail Marisa cornuarietis, Amer. J. Trop. Med. \& Hyg. 5 (2) 296$307,1956$.

2 Maldonado, J. F., and Acosta Martínez, J., The development of Schistosoma mansoni in the snail intermediate host, Australorbis glabratus, P.R. J. Pub. Health \&. Trop. Med. 22 (1) 331-57, 1946. 
These observations indicate that caution should be observed in introducing Marisa into areas where rice is grown by direct field-seeding. They also suggest that damage from Marisa would be negligible if 4-week-old or older

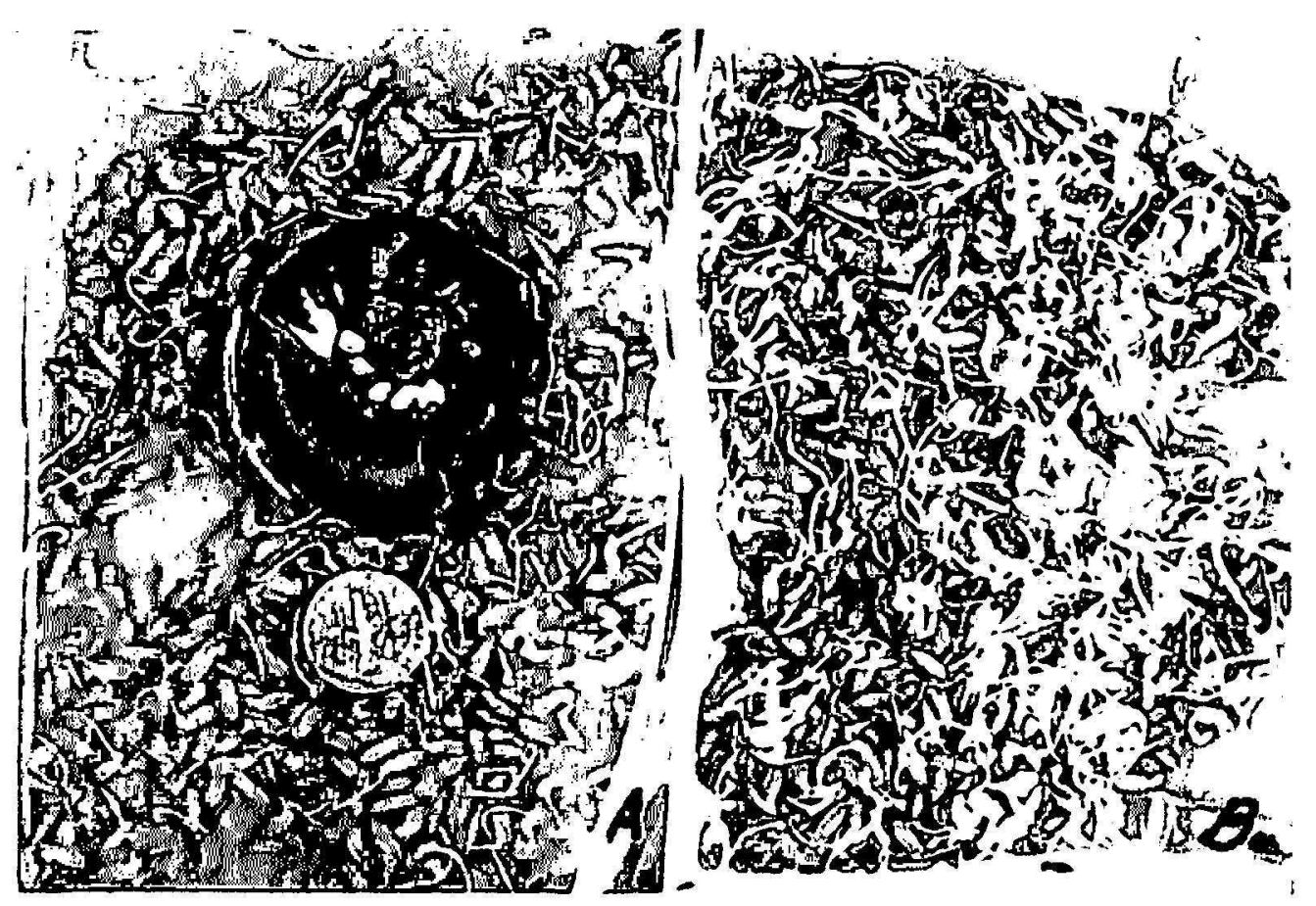

FIG. 1.-Damage caused by Marisa cornuarietis to young rice seedlings: A, Adult Marisa feeding on 72 -hour-old seedlings in the laboratory; $\mathrm{B}$, seedlings similar to those in $A$, but grown without the snatil. Note how few viable seedlings remain in $A$ as compared with $B$.

rice scedlings are used for transplanting into flooded fields. Since these tests were small, perhaps larger field-scale trials should be made before final conclusions are diawn.

Enrique Ortiz-Torres

Agronomist, Federal Experiment Station ARS, USDA, Mayagüez, P.R. 